\title{
Erratum to: Predictive value of serum HER2 ECD in patients with HER2-positive advanced gastric cancer treated with trastuzumab plus chemotherapy
}

\author{
Jun Zhou ${ }^{1} \cdot$ Zhi Peng $^{1} \cdot$ Yi Liu ${ }^{2} \cdot$ Jifang Gong ${ }^{1} \cdot$ Xiaotian Zhang $^{1} \cdot$ \\ Ming $\mathrm{Lu}^{1} \cdot$ Jing $\mathrm{Gao}^{1} \cdot \mathrm{Yili}^{\mathrm{Li}}{ }^{1} \cdot$ Yanyan $\mathrm{Li}^{1} \cdot \operatorname{Lin} \mathrm{Shen}^{1}$
}

Published online: 8 March 2016

(c) Japanese Society of Gastroenterology 2016

\section{Erratum to: J Gastroenterol (2015) 50:955-961 DOI 10.1007/s00535-015-1046-3}

In Table 2, clerical mistakes of the number of patients in low or high than $15.0 \mathrm{ng} / \mathrm{ml}$ were made. The number of patients with low than $15.0 \mathrm{ng} / \mathrm{ml}$ should be 40 , and high should be 25 . Table 2 should be shown as follows.

The original version of this article unfortunately contained error in Fig. 4a, the correct Fig. 4a is shown as follows.

The online version of the original article can be found under doi:10.1007/s00535-015-1046-3.

Zhi Peng

zhipeng3@ hotmail.com

Lin Shen

lin100@medmail.com.cn

1 Department of Gastrointestinal Oncology, Key Laboratory of Carcinogenesis and Translational Research (Ministry of Education), Peking University Cancer Hospital and Institute, FuCheng Road 52, HaiDian District, Beijing 100142, China

2 Translational Medicine Center, Laboratory of Oncology, Affiliated Hospital of Academy of Military Medical Sciences, Beijing, China 
Table 2 Correlation between basic HER2 ECD status response rates for AGC patients treated with trastuzumab

\begin{tabular}{|c|c|c|c|c|}
\hline \multirow[b]{2}{*}{ Parameter } & \multicolumn{4}{|l|}{ Baseline serum HER2 ECD } \\
\hline & Low $(n=40)(<15.0 \mathrm{ng} / \mathrm{ml})$ & $\operatorname{High}(n=25)(\geq 15.0 \mathrm{ng} / \mathrm{ml})$ & Low $(n=18)(<10.65 \mathrm{ng} / \mathrm{ml})$ & High $(n=47)(\geq 10.65 \mathrm{ng} / \mathrm{ml})$ \\
\hline Respond rate & 50.00 & 80.00 & 28.57 & 72.34 \\
\hline $95 \% \mathrm{CI}$ & $37.45-62.54$ & $69.96-90.04$ & $17.23-39.91$ & $61.13-83.55$ \\
\hline Odds ratio & 4.000 & & 6.538 & \\
\hline $95 \% \mathrm{CI}$ & $1.232-12.898$ & & $1.740-24.574$ & \\
\hline$P$ value & 0.017 & & 0.003 & \\
\hline
\end{tabular}

CI confidence index
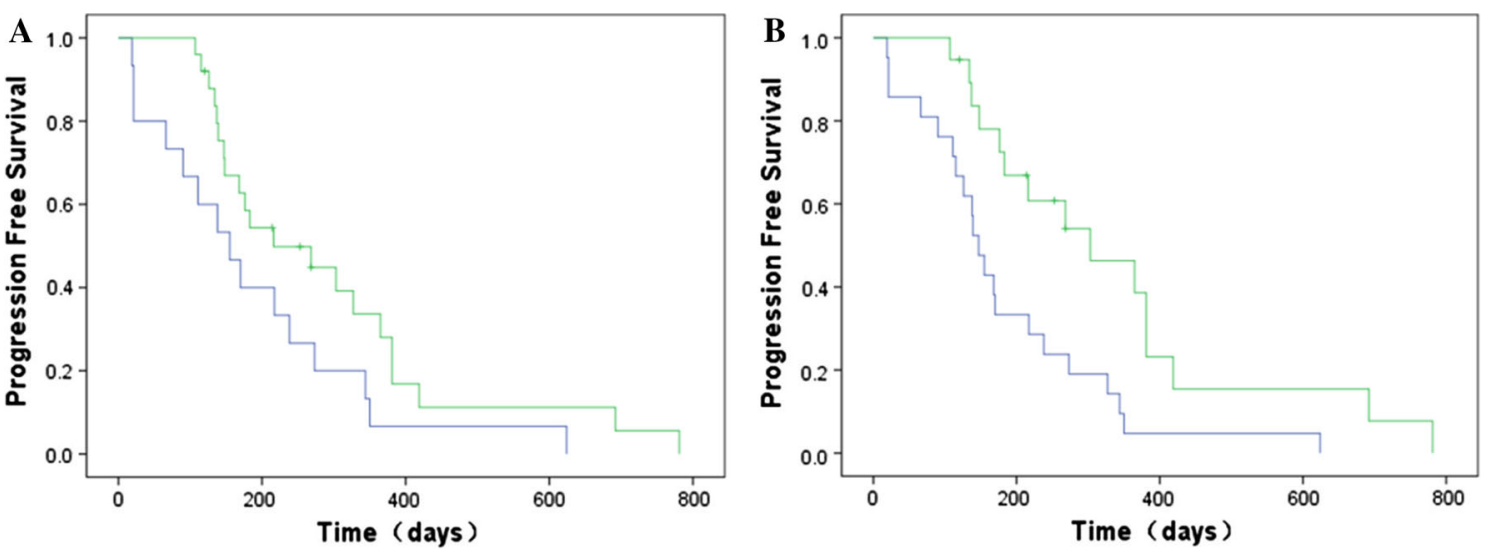

Fig. 4 Kaplan-Meier analysis of progression-free survival in patients with changes of serum HER2 ECD. a Serum HER2 ECD decline or not; b serum HER2 ECD decline $\geq 20 \%$ or not 